\title{
IMPLEMENTASI DECISION TREE BERBASIS ANALISIS TEKNIKAL UNTUK PEMBELIAN DAN PENJUALAN SAHAM
}

\author{
FX. Satriyo Dwi Nugroho \\ Alumnus Magister Manajemen Universitas Atma Jaya Yogyakarta
}

\begin{abstract}
The aim of this research is to develop decision support system using data mining decision tree method that is built base on technical analysis of financial market (EMA, MACD, OBV, RSI, and parabolic SAR). Those indicators are arranged as a trading rule that will help in buying and selling decision. The data used in this research are historical stock price in Jakarta Stock Exchange.

The result of this research indicates that generally the system can give number of transactions result in capital gains higher than number of transactions result in capital loss. The system also has capability to make decision with average gains are higher than decision with average losses. Investigation to profitability, geometric mean, cumulative wealth index, and sensitivity test to moving average gives the description whether stock can be traded based on technical analysis or not. This system can make easier in making decision for the users/investors that do not have enough knowledge and experiences in financial market.
\end{abstract}

Keywords: decision support system, data mining, decision tree, trading rules, technical analysis.

\section{LATAR BELAKANG MASALAH}

Sistem pendukung keputusan dapat diaplikasikan pada banyak bidang untuk membantu mempermudah mendapatkan keputusan dari data yang ada. Aplikasi sistem pendukung keputusan yang dapat dilakukan dalam dunia finansial adalah untuk pengambilan keputusan pembelian dan penjualan saham dari penggalian data historis. Salah satu metode dalam membuat sistem pendukung keputusan tersebut adalah dengan data mining. Pengambilan keputusan dalam data mining dilakukan dengan decision tree.

Data time series mengenai harga saham jumlahnya cukup besar dan menyimpan potensi informasi belum tergali. Data yang ada lalu diolah menggunakan decision tree classification. Informasi itu dianalisis dengan mengeneralisasi dalam kelas-kelas data sehingga data lebih mudah dibaca. Kelas-kelas tersebut menjadi bahan pertimbangan dalam melakukan pengambilan keputusan. Teori dasar yang dapat digunakan untuk membangun sistem pendukung keputusan untuk analisis finansial adalah analisis teknikal.

\section{KAJIAN LITELATUR}

\subsection{Efisiensi Pasar}

Pasar yang efisien digunakan untuk menggambarkan sebuah pasar yang memiliki semua informasi relevan mengenai sekuritas-sekuritas yang ada dan hal itu tercermin dalam harga sekuritas (Fama, 1970). Pada pasar yang efisien tingkat pengembalian selalu konsisten dengan tingkat resiko, pada kondisi tersebut investor tidak akan dapat memperoleh profit yang melebihi dari profit normal (Jones 2007).

Terdapat tiga tingkatan efisiensi pasar (Fama, 1970). Tingkatan yang pertama adalah pasar dalam bentuk lemah (weak form), pada tingkatan ini informasi yang tersedia di pasar adalah informasi mengenai data teknis 
perdagangan. Pasar tingkat kedua adalah pasar dalam bentuk setengah kuat (semi strong form), informasi yang beredar pada pasar ini meliputi informasi teknis perdagangan dan informasi publik (data fundamental perusahaan, laporan keuangan perusahaan, dan aksi perusahaan). Tingkatan ketiga adalah pasar dalam bentuk kuat (strong form), pada tingkatan ini semua perubahan informasi akan ditanggapi dengan cepat dengan pembentukan ekuilibrium harga yang baru berdasar informasi yang bersifat publik maupun informasi dalam perusahaan.

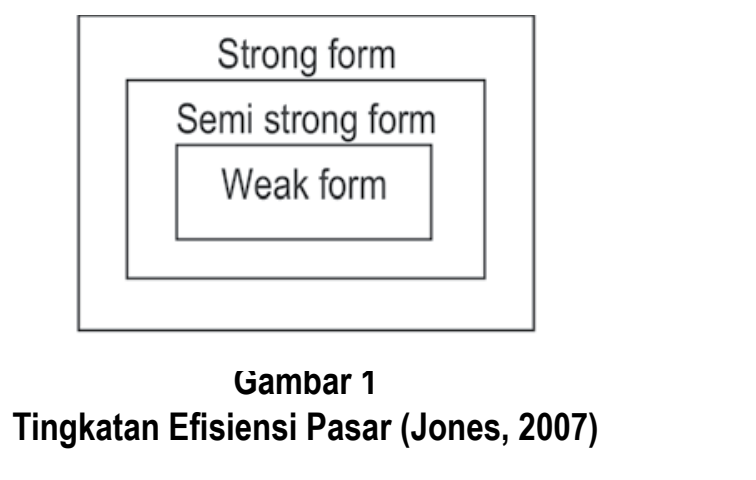

Pengujian untuk pasar dalam bentuk lemah banyak menggunakan technical trading rules, pasar hanya dianalisis secara teknikal tanpa penjelasan sebab akibat (Jones, 2007). Pada tingkatan pasar dalam bentuk setengah kuat pengujian lebih menekankan pada event study (Fama, 1970) dengan melihat terjadinya abnormal return pada setiap masa pengumuman informasi baru. Pada tingkatan pasar dalam bentuk kuat, pengujian dilakukan pada sekelompok pelaku pasar yang memiliki informasi yang tidak dipublikasikan mengenai nilai sekuritas, apakah return yang didapat pelaku pasar sama atau superioritas terhadap pelaku pasar yang tidak memiliki informasi tersebut.

Pasar modal bentuk kuat sudah melalui bentuk pasar lemah dan setengah kuat karena tingkatan pasar tersebut bersifat kumulatif (Hartono, 2005). Pasar dalam bentuk setengah kuat pasti memiliki ciri-ciri pasar dalam bentuk lemah namun tidak berlaku sebaliknya. Asumsi mengenai bentuk pasar modal di Indonesia tidak mendasari penelitian ini karena sifat bentuk pasar modal yang kumulatif tersebut. Penelitian ini mendekati pengujian untuk pasar dalam bentuk lemah menggunakan technical trading rules, namun tidak ditujukan untuk menguji bentuk pasar modal di Indonesia. Penelitian lebih ditujukan untuk mengamati profitabilitas, geometric mean return relative, dan cumulative wealth index dari setiap pengambilan keputusan yang diambil sistem untuk menganalisis perdagangan harian berorientasi spekulasi return berupa capital gain. Penelitian profitabilitas pertama berbasis analisis teknikal dilakukan oleh Alfred Cowless III pada tahun 1937 dengan mendasarkan perdagangan pada teorema Dow (Kirkpatrick dan Dahlquist, 2007). Analisis teknikal lebih berhubungan dengan probabilitas bukan pada kepastian, hal inilah yang membuat analisis teknikal dijadikan dasar untuk menyusun sistem pendukung keputusan untuk perdagangan spekulatif.

\subsection{Analisis Teknikal}

Analisis teknikal mendasarkan diri pada teorema Dow (dikembangkan Charles Dow awal abad 20). Dow menyatakan bahwa pasar yang ideal selalu terdiri dari trend naik, trend batas atas tertinggi, trend turun, dan trend batas bawah terendah (Kirkpatrick dan Dahlquist, 2007: 76). Pergerakan trend menurut Teorema Dow dibagi menjadi tiga: primary trend (pergerakannya berubah dalam hitungan tahun), secondary trend (pergerakannya dihitung dalam bulan dan minggu), dan minor trend (pergerakannya dihitung dalam hari) (Kirkpatrick dan Dahlquist, 2007). Analisis teknikal meneliti data masa lalu pasar finansial, dengan penggunaan chart sebagai alat untuk memprediksi trend (Murphy, 1999). Analisis teknikal mengidentifikasi perubahan trend pada tahap awal dan mengikuti trend sampai tanda-tanda baru menunjukkan trend sudah berubah (Pring, 2002: 3). Indikator yang dipilih menjadi trading rules merupakan indikator yang dipergunakan secara umum dan mendukung atau membangkitkan sinyal pembelian 
maupun penjualan. Proxy harga sistem ini menggunakan typical price, karena menurut Dimson dan Mussavian (2000), "Once returns series are based on end-of period prices, returns appear to fluctuate randomly". Supaya fluktuasi tidak terlalu mengganggu digunakan rata-rata harga harian yang disusun dengan typical price (total penjumlahan harga tertinggi, terendah, dan harga penutupan kemudian dibagi tiga).

Indikator yang akan disusun menjadi trading rules adalah

1. Exponential Moving Average

Exponential Moving Average (EMA) disusun dengan menjumlahkan sejumlah set data kemudian membaginya dengan waktu observasi (Pring, 2002: 155) dan menunjukkan trend data pada akhir observasi. EMA memiliki faktor weight untuk smoothing pada setiap observasinya yang akan berkurang secara eksponensial. Pemilihan periode observasi yang tepat pada moving average akan merefleksikan trend (Ya-lun Chou, 1975), jika tidak trend akan terlambat dari pergerakan sebelumnya.

2. Moving Average Convergence Divergence

Moving Average Convergence Divergence adalah indikator yang dikembangkan Gerald Appel. MACD menunjukkan perbedaan EMA dengan periode observasi pendek dengan yang panjang. MACD memiliki garis yang berlaku sebagai garis sinyal. Perbedaan antara MACD dan garis sinyal digambarkan dengan histogram nilainya menunjukkan kekuatan atau kelemahan harga.

3. Relative Strength Index

Relative Strength Index adalah analisis teknis berbentuk osilator yang menunjukkan kekuatan harga dengan membandingkan pergerakan naik dan turun yang berdekatan. $R S /$ cukup mudah diintepretasikan, teknik ini dikembangkan J. Welles Wilder (1978).

$R S I$ dihitung menggunakan EMA dengan pembobotan n hari. RSI memiliki nilai 1 sampai dengan 100 , dianggap terlalu banyak dibeli (overbought) jika nilainya melebihi batas atas (nilai yang biasa dipakai 70) dan dianggap terlalu banyak dijual (oversold) jika nilainya melebihi batas bawah (nilai yang biasa dipakai 30).

4. Parabolic Stop and Reverse (SAR)

Parabolic Stop and Reverse (SAR) juga dikembangkan oleh J. Welles Wilder untuk melihat trend. Parabola $S A R$ di bawah harga biasanya menunjukkan bullish dan di atas harga menunjukkan bearish. $S A R$ memiliki faktor akselerasi dengan nilai maksimum 0,2 faktor ini bertambah 0.02 saat nilai $E P$ terbentuk. Nilai $E P$ adalah nilai harga maksimum atau minimum dari periode pengamatan.

5. On Balance Volume

On Balance Volume merupakan indikator yang ditujukan untuk melihat relasi harga dan volume (Granville, 1975). Menurut O'Hara (1995), the price will depend on the size of the trade. OBV memiliki nilai kumulatif. Volume pada hari harga naik akan ditambahkan pada nilai OBV hari sebelumnya, volume pada hari harga turunkan dikurangkan pada nilai $O B V$ hari sebelumnya, dan pada hari tidak ada perubahan nilai $O B V$ sama dengan hari sebelumnya. OBV menunjukkan sinyal yang mengkonfirmasi harga, umumnya nilai $O B V$ akan meningkat atau menurun di hari harga bergerak ke arah yang dominan.

Trading rules tersebut akan di analisis dengan

1. Profitability

Profitability adalah analisis teknis yang digunakan untuk membandingkan performa dari beberapa sistem perdagangan atau beberapa investasi pada satu sistem (Harris, 2002).

$\mathbf{P}$ ofitability $=\frac{n \mathbf{P} \text { ofits }}{n \text { Trades }}-\frac{1}{(1+\operatorname{avg} \mathbf{P} \text { ovit } / \text { AvgLoss })}$

$n$ Profits merupakan jumlah transaksi yang memperoleh keuntungan, $n$ Trades merupakan jumlah 
transaksi keseluruhan yang sudah dilakukan, avgProfit merupakan rata-rata keuntungan, dan avgLoss merupakan rata-rata kerugian.

2. Geometric Mean dari Return Relative

Geometric Mean mengukur rata-rata pada periode yang relatif lama, karena tidak mengandung deviasi standar maka geometric mean dianggap lebih akurat untuk menghitung rata-rata harga yang pergerakannya sudah melalui beberapa periode yang berbeda.

$\mathrm{G}=\left[\left(1+T R_{1}\right)\left(1+T R_{2}\right)\left(1+T R_{3}\right) \ldots\left(1+T R_{\mathrm{n}}\right)\right]^{1 / \mathrm{n}}-1$

TR merupakan total return dari setiap transaksi yang dilakukan dihitung dengan menghitung selisih harga jual dengan harga beli saham kemudian dibagi dengan harga beli saham.

3. Cumulative Wealth Index

Cumulative wealth index merupakan kumulatif dari keseluruhan return relative. Cumulative wealth index menunjukkan seberapa besar kembalian total yang didapat dari nilai yang diinvestasikan.

CWI $=$ initiallnvestment $\left(1+T R_{1}\right)\left(1+T R_{2}\right)\left(1+T R_{3}\right) \ldots\left(1+T R_{n}\right)$

\subsection{Data Mining}

Data mining mempunyai pengertian sebagai proses penemuan pola informasi yang bermanfaat dan menarik di dalam kumpulan data besar dengan proses iterasi internal yang ditentukan melalui penemuan pola (Kantardzic, 2003: 2). Metode utama yang dilakukan oleh data mining (Balac, 2006): Classification adalah dengan menggolongkan data ke dalam beberapa kelas. Regression adalah fungsi yang mampu memetakan data dengan sebuah angka nyata (real-value) dari nilai variabel ramalan. Clustering adalah tugas deskriptif yang dipakai untuk mengidentifikasi suatu himpunan atau cluster kategorial. Summarization adalah tugas deskriptif tambahan untuk penemuan sebuah uraian ringkas dari keseluruhan atau sebagian data.

\section{Pengertian Classification Dalam Data Mining}

Classification merupakan pembelajaran suatu fungsi yang bersifat prediksi dan menggolongkan data ke dalam beberapa kelas (Kantardzic, 2003: 139). Metode classification by decision tree adalah sebuah struktur flow chart yang mirip seperti struktur pohon, setiap titik pohon merupakan atribut yang telah diuji, setiap cabang merupakan hasil uji, dan titik akhir merupakan pembagian kelas yang dihasilkan (Jiawei dan Kamber, 2001: 284318).

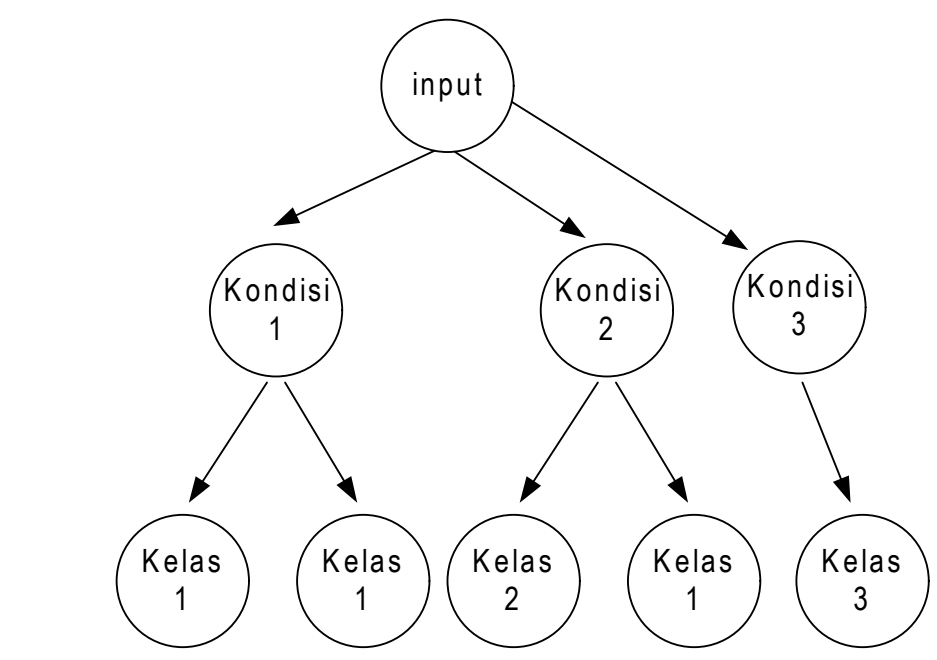

Gambar 2.

Struktur Decision Tree 


\subsubsection{Aplikasi Data Mining Pada Perdagangan Saham}

Secara umum metode data mining decision tree yang digunakan dalam analisis finansial cenderung memerlukan lebih banyak data historis daripada pemodelan biasa (Langdell, 2002). Variabel data return stock market yang relevan untuk bisa dimasukkan ke sistem adalah data time series, seperti data harga pembukaan, harga penutupan, harga tertinggi, harga terendah, index, dan volume.

Contoh trading rules

IF CONDITION1 AND CONDITION2

THEN ACTION

Condition1 dan Condition2 diambil dari pola data yang sudah ada dengan metode decision tree. Misalnya data historis yang sudah dikumpulkan dan diproses memiliki kondisi hasil perhitungan moving average 5 hari menembus ke atas nilai moving average 10 hari dan kedua moving average tersebut bergerak ke atas maka nilai data masuk ke dalam kelas buy (Langdell, 2002).

Trading rules dalam penelitian ini digunakan sebagai condition atau simpul pengujian yang digunakan dalam decision tree. Trading rules ini sudah ditetapkan sebelumnya dan tidak dapat diubah kecuali dengan mengubah sistem, dalam trading rules yang selalu dapat berubah secara dinamis adalah value di dalam setiap indikator dengan mengikuti data yang dimasukkan ke dalam sistem.

\section{METODOLOGI PENELITIAN}

\subsection{Sampel}

Data harga saham yang digunakan adalah data harga saham time series yang kemudian dikalkulasi sehingga menghasilkan value untuk EMA, MACD, RSI, parabolic SAR, dan OBV untuk kemudian disimpan dalam database untuk digunakan sebagai value dalam trading rules. Data harga saham yang sama diuji menggunakan decision tree dengan value dalam trading rules yang sudah disimpan dalam database. Decision tree tersebut dan akan menghasilkan classification untuk setiap subset data, yaitu kelas buy, sell, dan hold. Kelas data ini dimasukkan kembali ke dalam decision tree berikutnya untuk memberi bobot atas keputusan yang sudah diambil.

\subsection{Alat Analisis}

Analisis dilakukan dengan mengamati profitabilitasnya, nilai-nilai harga pada pasangan kelas buy dan sell akan dibandingkan, apakah nilai jual lebih tinggi dari nilai beli sehingga keputusan tersebut menguntungkan atau malah sebaliknya, dihitung juga geometric mean return relative dan cumulative wealth index untuk menunjukkan hasil akhir dari keseluruhan pengambilan keputusan. Sistem ini tidak memperhitungkan biaya transaksi dalam menghitung gain dan loss. Sistem juga tidak mengijinkan adanya short selling. Analisis sensitifitas dilakukan terhadap value EMA sehingga dapat diketahui karakteristik pergerakan harga saham. 


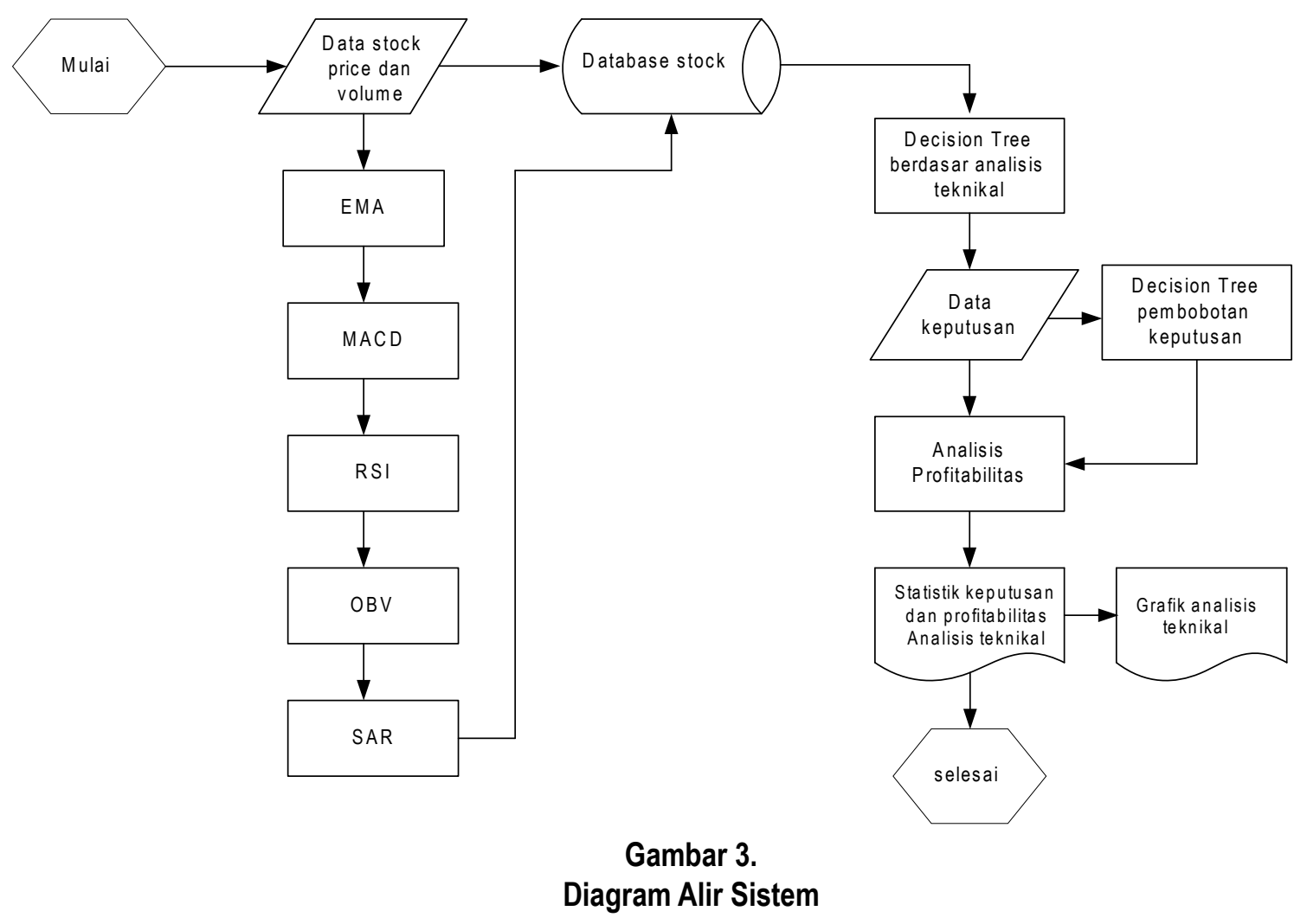

\section{ANALISIS DATA}

\subsection{Decision Tree}

Pada program aplikasi terdapat dua tahap decision tree. Pada decision tree tahap pertama data harga akan diuji dengan indikator-indikator EMA dan parabolic SAR yang mampu menghasilkan signal jual dan beli secara jelas. Decision tree ini akan menghasilkan kelas sell, buy, dan hold. Pada decision tree tahap kedua data kelas sell dan buy diuji dengan indikator-indikator EMA, parabolic $S A R, R S I, O B V, M A C D$, dan Volume yang menghasilkan bobot dari setiap kelas sell dan buy.

1. Trading Rules Pada Decision Tree Tahap Pertama

Trading rules yang digunakan pada decision tree tahap pertama adalah sebagai berikut, uji harga pada hari $(\mathrm{t})$ :

2. Trading Rules Pada Decision Tree Tahap Kedua

Trading rules yang digunakan pada decision tree tahap kedua adalah sebagai berikut, uji kelas pada hari (t) kelas buy dan sell akan diberi bobot awal nol, pada setiap harga di hari (t) bobot akan diakumulasikan terhadap indikator EMA, parabolic SAR, MACD, RSI, OBV, dan Volume sehingga pembobotan memiliki jangkauan nilai dengan bernilai maksimal 7 (tujuh) dan bernilai minimal -7 (negatif tujuh). Nilai maksimal menunjukkan bahwa keputusan pengambilan kelas buy atau sell dianggap sangat tepat karena didukung oleh semua indikator yang ditetapkan dalam trading rules, dan nilai negatif tujuh dianggap sebaliknya. Pada decision tree tahap kedua data dihasilkan kelas untuk sell dan buy berdasarkan bobot pengujian. Kelas sell dibagi menjadi 15 (lima belas kelas) yaitu sell(7), sell (6), sell (5), sell (4), sell (3), sell (2), sell (1), sell (0), sell (-1), sell (-2), sell (-3), sell $(-4)$, sell $(-5)$, sell $(-6)$, sell $(-7)$. Kelas buy dibagi menjadi 15 (lima belas kelas) yaitu buy (7), buy (6), buy (5), buy (4), buy (3), buy (2), buy (1), buy (0), buy (-1), buy $(-2)$, buy $(-3)$, buy $(-4)$, buy $(-5)$, buy $(-6)$, buy $(-7)$. 


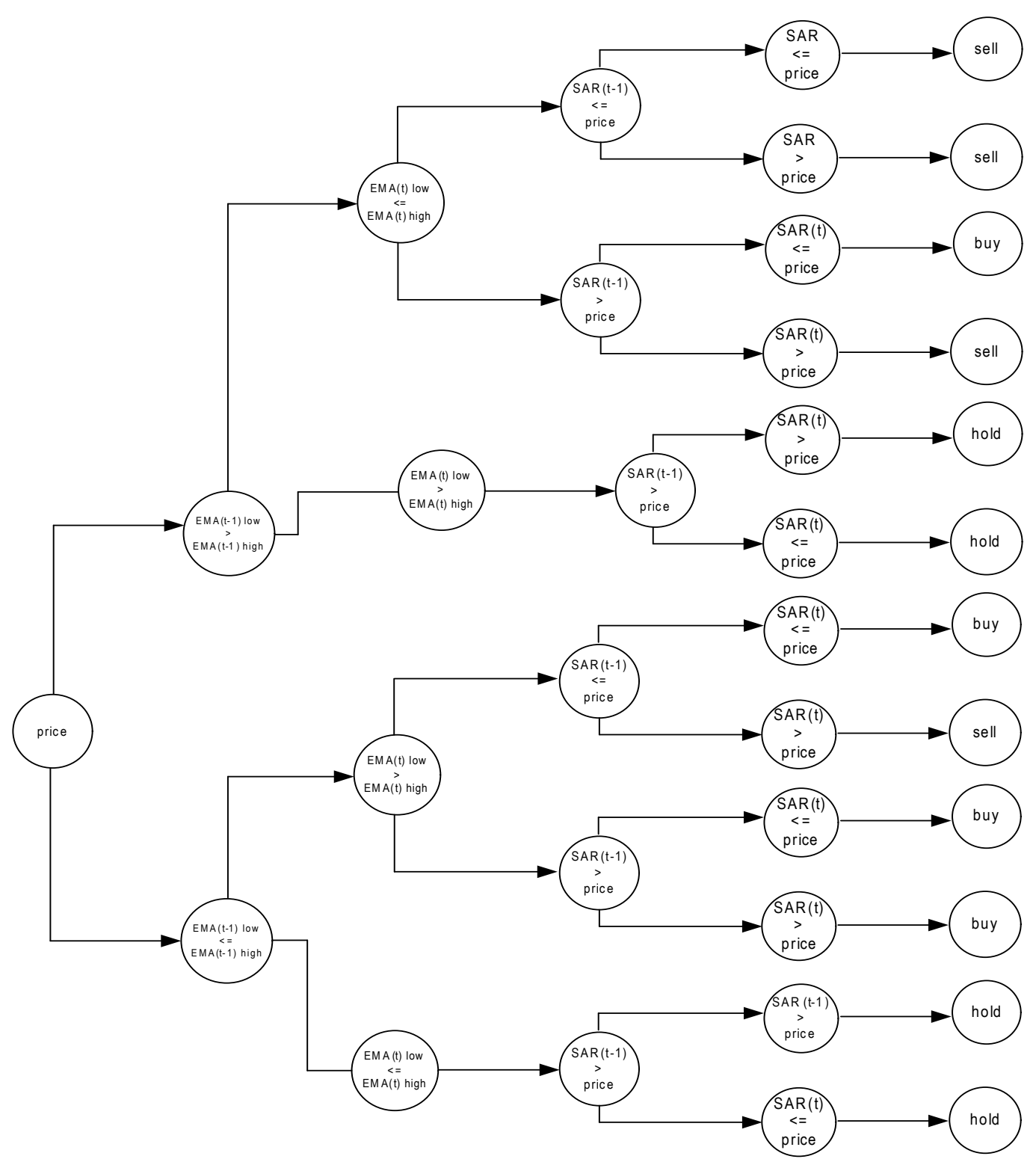

Gambar 3.

Decision Tree Tahap Pertama

\subsection{Data Pengujian}

Data harga saham historis dipilih dengan kriteria:

1. Perusahaan emiten masuk ke dalam indeks LQ45 yang merupakan index 45 (empat puluh lima) sahamsaham pilihan, yang memiliki likuiditas tinggi dan kapitalisasi pasar yang kuat. Kriteria index LQ45: masuk dalam 60 saham tertinggi dari total transaksi pasar reguler (rata-rata nilai transaksi dalam 12 bulan terakhir), masuk dalam saham-saham dengan nilai kapitalisasi saham tertinggi (rata-rata nilai kapitalisasi pasar dalam 12 bulan terakhir), terdaftar di Bursa Efek Jakarta sekurang-kurangnya 3 (tiga) 
bulan, memiliki kondisi finansial yang bagus, prospek untuk pertumbuhan, frekuensi (www.jsx.co.id/ faq/default.aspx).

2. Saham terdaftar dalam index LQ 45 selama 5 (lima) periode berturut-turut, mulai periode Agustus 2005-Januari 2006, Februari 2006-Juli 2006, Agustus 2006-Januari 2007, Februari 2007-Juli 2007, dan Agustus 2007-Januari 2008.

3. Memiliki data transaksi perdagangan minimal 1095 hari perdagangan mulai 22 April 2003 sampai 31 Juli 1007.

Kriteria tersebut dimaksudkan untuk mendapatkan data harga saham perusahaan-perusahaan yang likuid dan memiliki rentang data yang melalui beberapa periode siklus trend pasar (primary trend, secondary trend, minor trend) dalam teorema Dow.

Tabel 1.

Perusahaan Emiten yang Memenuhi Kriteria Data Pengujian

\begin{tabular}{|c|c|c|c|c|c|c|}
\hline Ticker & Perusahaan & Tanggal berdiri & Tanggal listing & Kapitalisasi & Sektor & Subsektor \\
\hline & Astra Agro Lestari & & & & 18 & \\
\hline AALI & $\begin{array}{l}\text { Tbk. } \\
\text { Astra International }\end{array}$ & 3-Oct-1988 & 12-Sep-1997 & $6,229,129,032,258$ & Pertanian & $\begin{array}{l}\text { Perkebunan } \\
\text { Otomotif dan }\end{array}$ \\
\hline ASII & Tbk. & 20-Feb-1957 & 4-Apr-1990 & $1,646,520,202,020$ & $\begin{array}{l}\text { Aneka Industri } \\
\text { Infrastruktur }\end{array}$ & Komponennya \\
\hline BLTA & $\begin{array}{l}\text { Berlian Laju Tanker } \\
\text { Tbk. }\end{array}$ & 13-Feb-1981 & 26-Mar-1990 & $57,743,764,674$ & $\begin{array}{l}\text { Utilitas dan } \\
\text { Transportasi }\end{array}$ & Transportasi \\
\hline BNBR & Bakrie \& Brothers Tbk. & 13-Mar-1951 & $20-4 g^{2}-1909$ & $37,031,181,852$ & $\begin{array}{l}\text { Perdagangan, } \\
\text { Jasa dan } \\
\text { Investasi }\end{array}$ & $\begin{array}{l}\text { Perusahaan } \\
\text { Investasi } \\
\text { Pertambangan }\end{array}$ \\
\hline BUMI & Bumi Resources Tbk. & 26-Juni-1973 & & $237,600,000,000$ & Pertambangan & $\begin{array}{l}\text { Batubara } \\
\text { Jalan Tol, }\end{array}$ \\
\hline & $\begin{array}{l}\text { Citra Marga } \\
\text { Nusaphala Persada }\end{array}$ & & & & $\begin{array}{l}\text { Infrastruktur } \\
\text { Utilitas dan }\end{array}$ & $\begin{array}{l}\text { Pelabuhan, } \\
\text { Bandara, dan }\end{array}$ \\
\hline CMNP & Tbk. & & 1-Oct-1995 & $1,125,000,000,000$ & $\begin{array}{l}\text { Transportasi } \\
\text { Industri }\end{array}$ & Sejenisnya \\
\hline INDF & $\begin{array}{l}\text { Indofood Sukses } \\
\text { Makmur Tbk. } \\
\text { Indah Kiat Pulp \& }\end{array}$ & 14-Aug-1990 & 14-Jul-1994 & $302,738,709,677$ & $\begin{array}{l}\text { dan Barang } \\
\text { Konsumsi } \\
\text { Industri Dasar }\end{array}$ & $\begin{array}{l}\text { Makanan dan } \\
\text { minuman }\end{array}$ \\
\hline INKP & $\begin{array}{l}\text { Paper Tbk. } \\
\text { Kawasan Industri }\end{array}$ & 7-Dec-1976 & 7-Jun-1990 & $3,165,760,180,774$ & $\begin{array}{l}\text { dan Kimia } \\
\text { Property dan }\end{array}$ & $\begin{array}{l}\text { Pulp dan Kertas } \\
\text { Property dan }\end{array}$ \\
\hline KIJA & $\begin{array}{l}\text { Jababeka Tbk. } \\
\text { PP London Sumatera }\end{array}$ & 12-Jan-1989 & 1-Oct-1995 & $64,782,889,101$ & Real Estate & Real Estate \\
\hline LSIP & Tbk. & 14-Sep-1963 & 7-May-1996 & $344,629,290,323$ & Pertanian & $\begin{array}{l}\text { Perkebunan } \\
\text { Pertambangan }\end{array}$ \\
\hline MEDC & $\begin{array}{l}\text { Medco Energi } \\
\text { International Tbk. } \\
\text { Bank Pan Indonesia }\end{array}$ & 6-Sep-1980 & 10-Dec-1994 & $169,407,931,034$ & Pertambangan & $\begin{array}{l}\text { Minyak dan Gas } \\
\text { Bumi }\end{array}$ \\
\hline PNBN & $\begin{array}{l}\text { Tbk. } \\
\text { Tambang Batubara }\end{array}$ & 17-Aug-1971 & 29-Dec-1982 & $170,872,069,065$ & Keuangan & $\begin{array}{l}\text { Bank } \\
\text { Pertambangan }\end{array}$ \\
\hline PTBA & Tbk. & 15-Dec-1980 & 23-Dec-2002 & $12,325,630,434,783$ & $\begin{array}{l}\text { Pertambangan } \\
\text { Industri Dasar }\end{array}$ & Batubara \\
\hline SMCB & Hocim Indonesia Tbk. & 15-Jun-1971 & 8-Oct-1997 & $58,046,467,500$ & $\begin{array}{l}\text { dan Kimia } \\
\text { Perdagangan, } \\
\text { Jasa dan }\end{array}$ & $\begin{array}{l}\text { Semen } \\
\text { Perdagangan } \\
\text { Besar Barana }\end{array}$ \\
\hline UNTR & United Tractors Tbk. & 11-Jan-1901 & 19-Sep-1989 & $458,350,344,828$ & Investasi & Produksi \\
\hline
\end{tabular}

sumber : diolah dari data http://www.jsx.co.id 


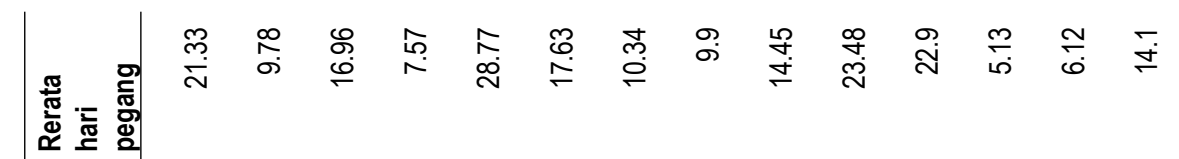
든

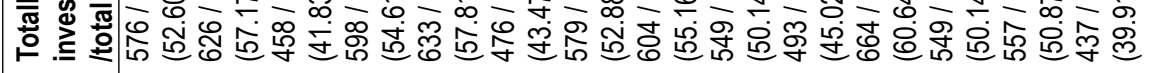

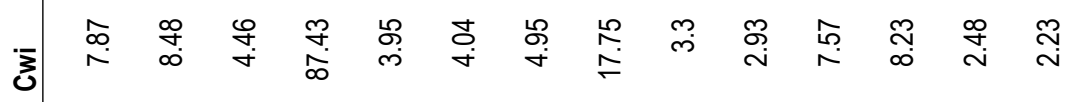

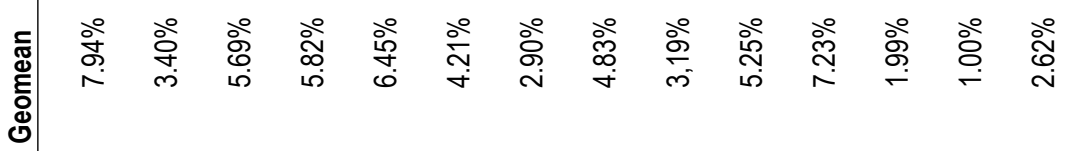
䓂

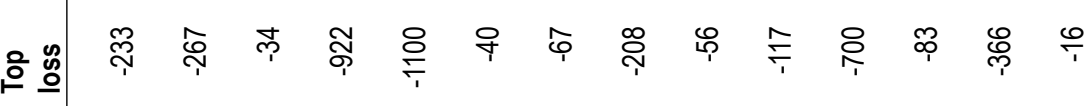

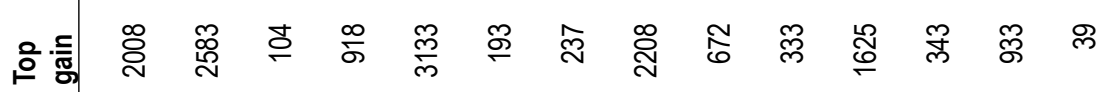
定兽

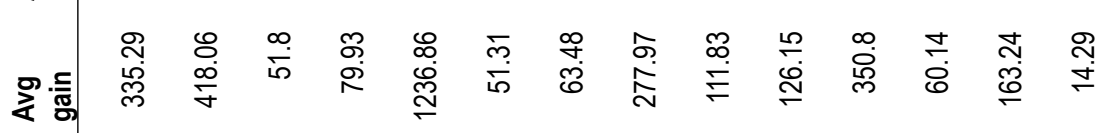

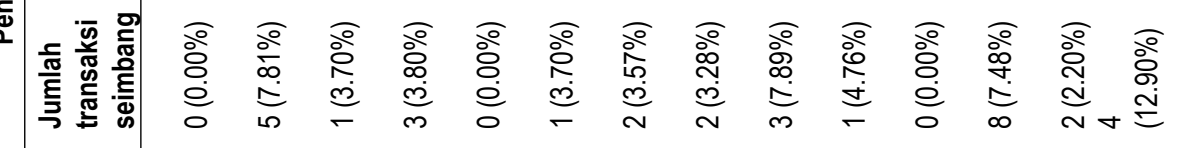

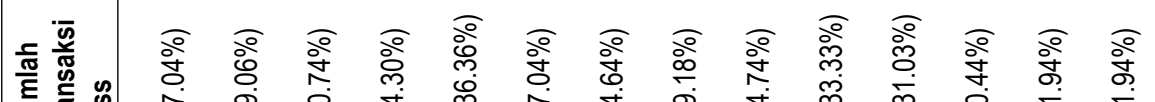

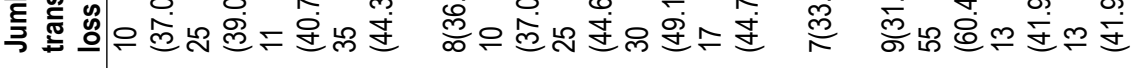

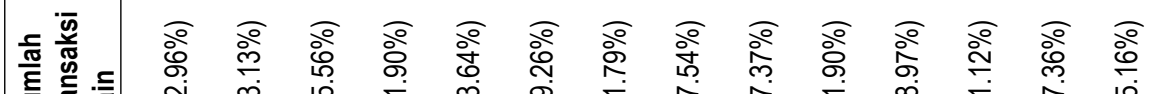

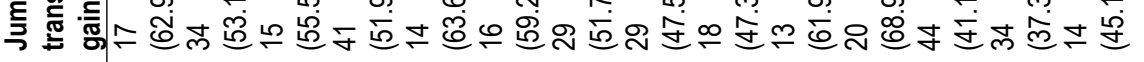

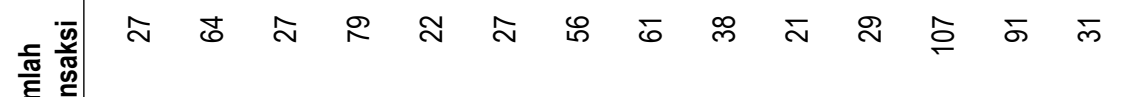
焉

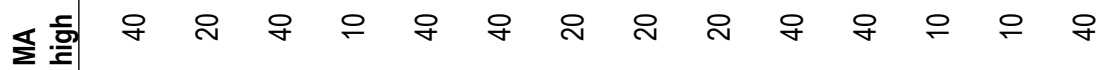
뜬으

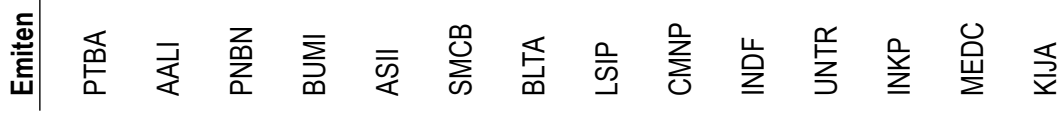




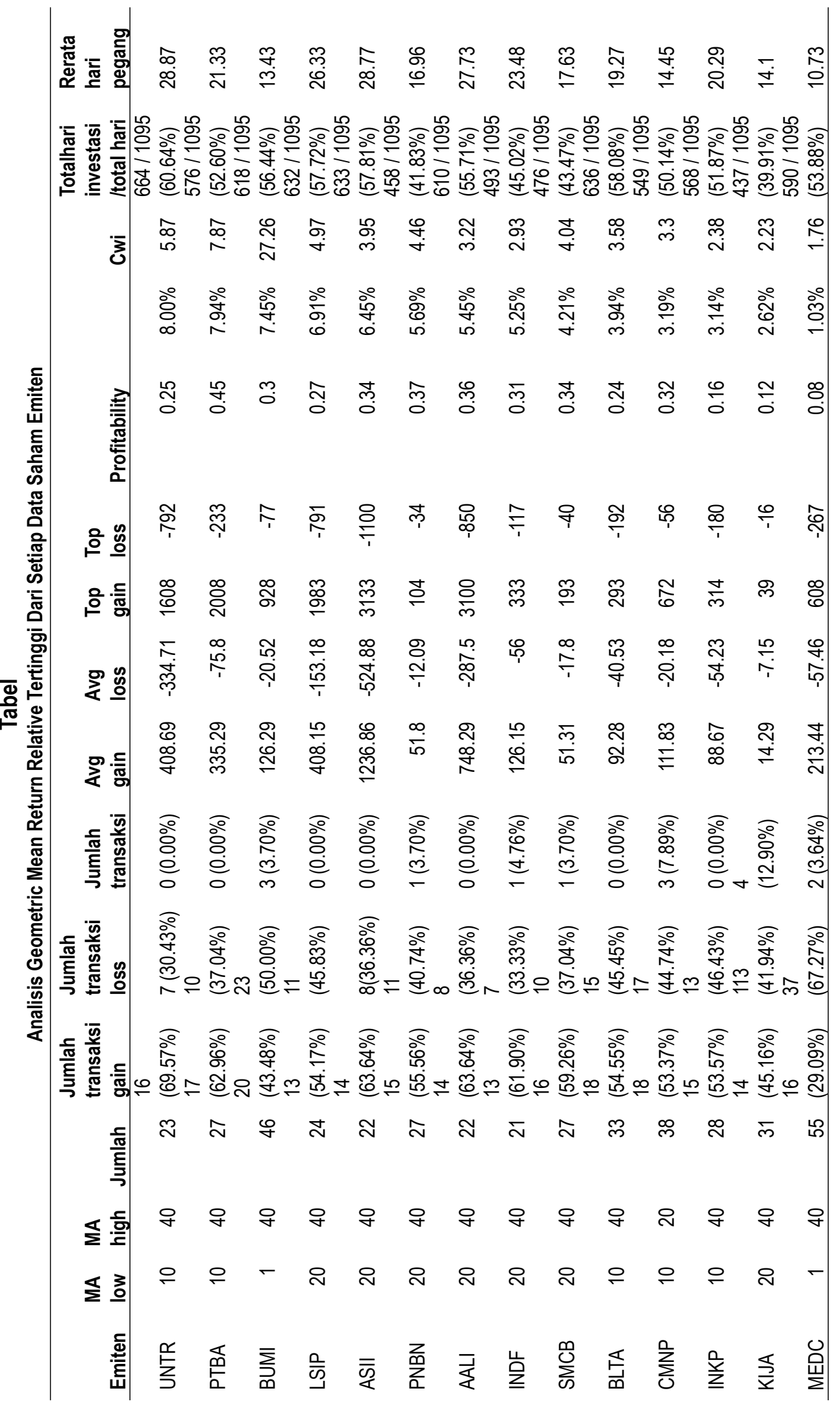




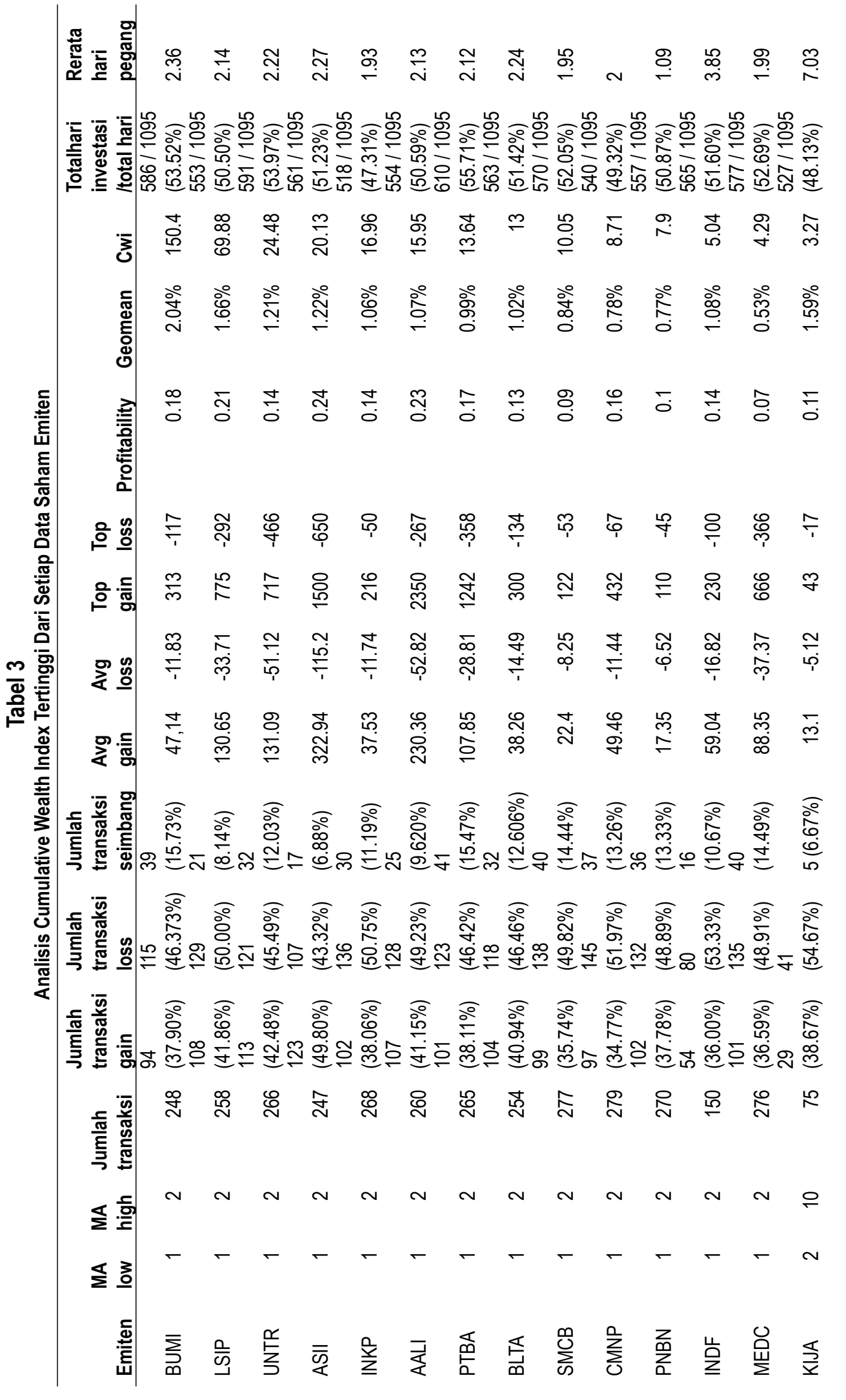




\section{PENUTUP}

Sistem pendukung keputusan decision tree yang dibangun berdasarkan analisis teknikal mampu memberikan gambaran saat saham diperdagangkan hanya berdasarkan pergerakan trend. Perdagangan berdasarkan pergerakan trend ini bersifat spekulasi namun cukup mampu memberikan keuntungan. Tidak semua keputusan yang diambil oleh sistem memberikan keuntungan kepada hasil akhir transaksi, namun dari total transaksi yang dilakukan selama masa periode penelitian umumnya sistem dapat memberikan jumlah transaksi yang menghasilkan capital gain lebih besar dari capital loss. Saat jumlah transaksi yang menghasilkan gain lebih kecil dari transaksi loss, sistem juga masih mampu memberikan keputusan yang menghasilkan rata-rata gain lebih besar dari rata-rata loss dari setiap keputusan transaksi yang dilakukan.

Pengamatan terhadap ketiga pengujian yaitu profitabilitas, geometric mean, dan cumulative wealth index yang dilakukan dan ditambah dengan pengujian sensitifitas moving average memberikan gambaran mengenai data harga saham historis dari emiten mana saja yang cocok diperdagangkan berdasarkan analisis teknikal dan data mana yang lebih cocok diperdagangkan dengan analisis yang lain.

Penggunaan indikator teknikal yang lebih banyak dapat membuat akurasi sistem menjadi lebih baik. Serial data dengan satuan waktu yang lebih kecil, misalnya pergerakan harga intraday juga akan memberikan keputusan yang lebih akurat. Analisis fundamental sederhana, seperti rasio keuangan yang umum (seperti EPS, PER, PBV) pada perusahaan dapat ditambahkan dalam sistem sebagai awal pemilihan emiten yang akan dianalisis secara teknikal.

\section{DAFTAR PUSTAKA}

Appel, Gerald. (1960) “The Moving Average Convergence-Divergence Trading Method".

Balac, Natasha. (2006) "Introduction to Data Mining".

Harris, Michael. (2002) "Improve Your System With The Profitability Rule". Technical Analysis of Stock and Commodities Magazine.

Joseph E. Granville, (1976) “Granville's New Strategy of Daily Stock Market Timing for Maximum Profi”. Prentice-Hall, -Inc..

Kantardzic, Mehmed. (2003) Data Mining : Concepts, Models, Methods, and Algorithms. John Willey's and Sons Inc.. AZ: USA.

Jiawei Han dan Micheline Kamber. (2001) Data Mining: Concept and Techniques. Academic Press. CA: USA.

Langdell, Stephen.(2002). “Examples of The Use of Data Mining in Financial Applications”. Numerical Algorithms Group.

Murphy, John J.(1999) "Technical Analysis of the Financial Markets". New York Institute of Finance.

O' Hara, Maureen.(1995) Market Microstructure Theory. BlackWell Business. MA: USA.

Pring, Martin J.(2002) Technical Analysis Explained. McGraw-Hill. NY: USA.

Wilder, J. Welles.(1978) "New Concepts in Technical Trading Systems".

Ya-lun Chou.(1975) "Statistical Analysis". Holt International.

\section{Website}

